\title{
Spatial politics and infrastructure development: Analysis of historical transportation data in Gauteng - South Africa $(1975-2003)$
}

Abstract

If South Africa's Gauteng Province is to become a more 'sustainable', urbanised region, attention needs to be paid to building a transportation network that aligns with sustainable development principles. Currently, public transport passenger levels are low, whilst the geographical area it serves is large and becoming larger. This study analysed the long term, historical transportation trends of Gauteng by comparing four transport studies undertaken between 1975 and 2003. It reveals that an adherence to the 'predict and provide' transportation planning model has systematically enhanced road infrastructure over rail, and private over public transport. Effective, efficient and low cost public transport has been systematically under-provisioned; while a reliance on private vehicles is now entrenched and systemic. Racial segregation, spatial apartheid and weak urban land use planning, has resulted in an entrenched, low-density urban sprawl. Lastly, there is the need to collect comparable, longitudinal transportation data, if the successes and failures of policies are to be monitored.

Keywords

Sustainable transport • landuse planning $\cdot$ public transport $\bullet$ predict and provide model

(c) University of Warsaw - Faculty of Geography and Regional Studies

\author{
Tracey McKay', Zach Simpson ${ }^{2}$, \\ Naeem Patel ${ }^{3}$ \\ ${ }^{1}$ Environmental Sciences, University of South Africa, \\ South Africa \\ e-mail: mckaytjm@unisa.ac.za \\ ${ }^{2}$ Faculty of Engineering and the Built Environment, \\ University of Johannesburg, South Africa \\ e-mail: zsimpson@uj.ac.za \\ ${ }^{3}$ Faculty of Engineering and the Built Environment, \\ University of Johannesburg, South Africa \\ e-mail: npatel@eskom.co.za \\ Received: 7 November 2016 \\ Accepted: 13 February 2017
}

\section{Introduction}

One of the guiding principles of sustainable cities or regions is that they have a transportation network and infrastructure that is pedestrian friendly, encourages cycling, reduces dependence on cars, minimises traffic congestion and has an integrated, cost-efficient public transport system (Garner et al 2001; Zhao 2010). The Gauteng Province, South Africa's most populous and economically developed province, and its cities, are far from attaining such status (Venter \& Badenhorst 2014). Gauteng has struggled with poor access - for both its rich and poor residents - to cost-efficient transportation networks, although the wealthy are far less directly impacted by the inferior public transportation infrastructure than the poor (Simon 1992; Beavon 2001; Berg et al. 2015; Schoeman 2015). Historically, there has been a deficit of good, cheap and reliable public transportation, with poor - mainly black African ${ }^{1}$ - people enduring the brunt of this. The province also suffers from a lack of regional connectivity. Consequently, individuals rely on private and quasi-public forms of transport (motor vehicles, and privately operated minibus taxis) for their commuting needs. This, in turn, results in a build-up of motor vehicles on the roads, causing excessive, on-going, recurrent and non-recurrent traffic congestion. Anecdotally, many Gauteng road users actively plan their days around avoiding congestion, and the various reported road rage incidents of recent years could indicate that tolerance levels have reached a nadir (Murray 2011). Such congestion is not good for the province as it leads to loss of

'In South Africa's past, people of colour, that is black Africans, Indians and Coloured people (mixed race) experienced multiple forms of discrimination such as, but not limited to, legal and economic discrimination. Levels of discrimination varied with black African people experiencing the worst thereof. income, decreased economic activity, inhibited job creation and increased living costs (Serageldin 1993; Schoeman 2015).

This study sought to conduct a longitudinal analysis of historical travel data in the Gauteng Province, as transportation engineering and the development of transportation infrastructure relies heavily on the predictions of future travel demand using past trends. The longitudinal analysis of data also provides for perspective and insight into the effects of historical events, demographic shifts, and economic and political policies on travel patterns and transportation infrastructure development. In the case described here, data from four transport surveys undertaken by the national and/or provincial governments of the day between 1975 and 2003 was analysed and compared. To date, such an undertaking has not been recorded, nor has there been a longterm comparative study of transportation data and, therefore, this study represents the first attempt of its kind. As will be shown in this paper, the transport challenges facing the Gauteng Province are intricately tied to the historical land use policies deployed in the province.

Addressing the challenges associated with poor public transport

Unless a city or region has a user-friendly, cost-effective and integrated transportation network, transport costs become a significant burden (Schoeman 2015). This burden is most heavily borne by economically and geographically vulnerable residents, which exacerbates income inequality (Berg et al. 2015). Thus, deliberate attempts to reduce such transport poverty (a situation where access to affordable and safe transportation is limited) 
are an essential element of a sustainable transportation policy. Sustainable transportation, however, also involves the active integration of transportation with land use planning (Mattingly \& Morrissey 2014). If this is not done, then automobile dependence is induced and increases over time (Hamidi \& Ewing 2014). Furthermore, a negative feedback loop develops whereby automobile dependence increases demand for roads and parking spaces. The provision of these elements leads to additional low-density urban expansion. Concomitantly, urbanites undergo a perception shift, coming to view motor vehicle usage as a necessity and so actively aspiring to shift to private transport (Rooney 2014). As poorer people usually cannot afford cars, they become even more marginalised, increasing social inequality and reducing a sense of common community (Burgess 2000; Berg et al. 2015).

The most commonly acknowledged result of automobile dependence, however, is congestion (Serageldin 1993; Chakwizira 2007). Traditionally, the challenge of congestion has often been addressed through the application of the so-called 'predict and provide' transport model, whereby future projections of demand for road services are generated and ever-increasing roadway is provided to meet this demand. However, cities need a particular density (of people, businesses, services) to function effectively and efficiently which, it is argued herein, the 'predict and provide' model can undermine. The model also does not curb automobile dependence.

Congestion can be better addressed using Travel Demand Management (TDM) strategies (see Rodrigue et al. 2006 and Garner et al. 2001 for a summary of these strategies), or through Transit Oriented Development (TOD) (Stapelberg 2006). TOD is a development style based on mixed residential and commercial activities, which effectively support a public transport network. The most viable and environmentally sustainable approach to dealing with congestion, however, is to combine TOD with densification (Harden 2011). Densification means increasing the number of residential units per square kilometre of developed land (Galster et al. 2001). Densely settled areas enable greater numbers of people to easily access transport stations, reduces public transport's dependence on government subsidies (due to increased ridership levels) and leads to improved customer experiences as economies of scale come into play. However, densification has to go hand in hand with mixed land use (commercial, residential and leisure developments in close proximity) in order to fully integrate public transport with the urban environment (Scheiner 2010; Beukes \& Vanderschuren 2011). There is thus a strong link between mixed use densification and an effective transportation system. Therefore, sustainable transportation systems must include policies of densification (Burgess 2000).

A spatial and historical background to Gauteng's transport challenges

Land use and transportation in Gauteng have been shaped in several significant ways. Firstly, the nature of the gold-bearing Witwatersrand reef, which runs from west to east, has resulted in a string of towns - now cities - such as Springs, Benoni, Boksburg, Roodepoort, Krugersdorp and Randfontein being founded over a large geographical area. In addition, the province has a strong 'pull' in a northerly direction, due to the geographical location of Pretoria (now Tshwane), one of South Africa's capital cities. There is also a pull to the south, towards the Vaal River, for a combination of historical and industrial reasons. The result of this north-south pull has been the establishment of towns such as Vanderbijlpark, Midrand and Centurion (the last two may be argued by some to be types of 'edge cities' as defined by Garreau, 1991). Thus, the province has abnormally extended east-west and north-south axes (Beavon 2004). At the 'centre' of these axes is the city of Johannesburg, which itself has extended east-west and north-south axes, mimicking the spatial pattern of the province (see Figure 1).

Additionally, many of the other cities/towns within Gauteng also mimic the north/south axis of Johannesburg and the province (Beavon 2004). There are a number of reasons for this. Firstly, 'better' residential land is found to the north of the gold reef (prompting the establishment of residential areas - initially for white people only) due to prevailing winds and the dumping of mine waste (mine dumps, slimes dams and waste water ponds) to the south of the reef. Secondly, apartheid planning saw the allocation of this less desirable land in the south to black African, Coloured and Indian people, giving rise to the establishment of residential areas for these racial groups to the south of the reef (Beavon 2004). However, spatial apartheid also called for these racial groups to be 'as invisible as possible' and so their residential areas were located far from the CBD and 'white residential areas'. Consequently, residential areas for Black, Coloured and Indian people (Soweto, Lenasia, Ennerdale, Katlehong, Tsakane, Vosloorus, Daveyton, Tembisa and the like) were deliberately located in peri-urban space (Parnell \& Beavon 1996; Murray 2011). This racial segregation fundamentally shaped the provincial transportation network (Beavon 2001; 2004).

Thus, segregationist policies and, later on, apartheid have had a profound effect on land use and transportation, serving to exacerbate the extent of urban sprawl, normalising and entrenching low-density housing developments, and promoting single land use policies. Nevertheless, as detailed here,

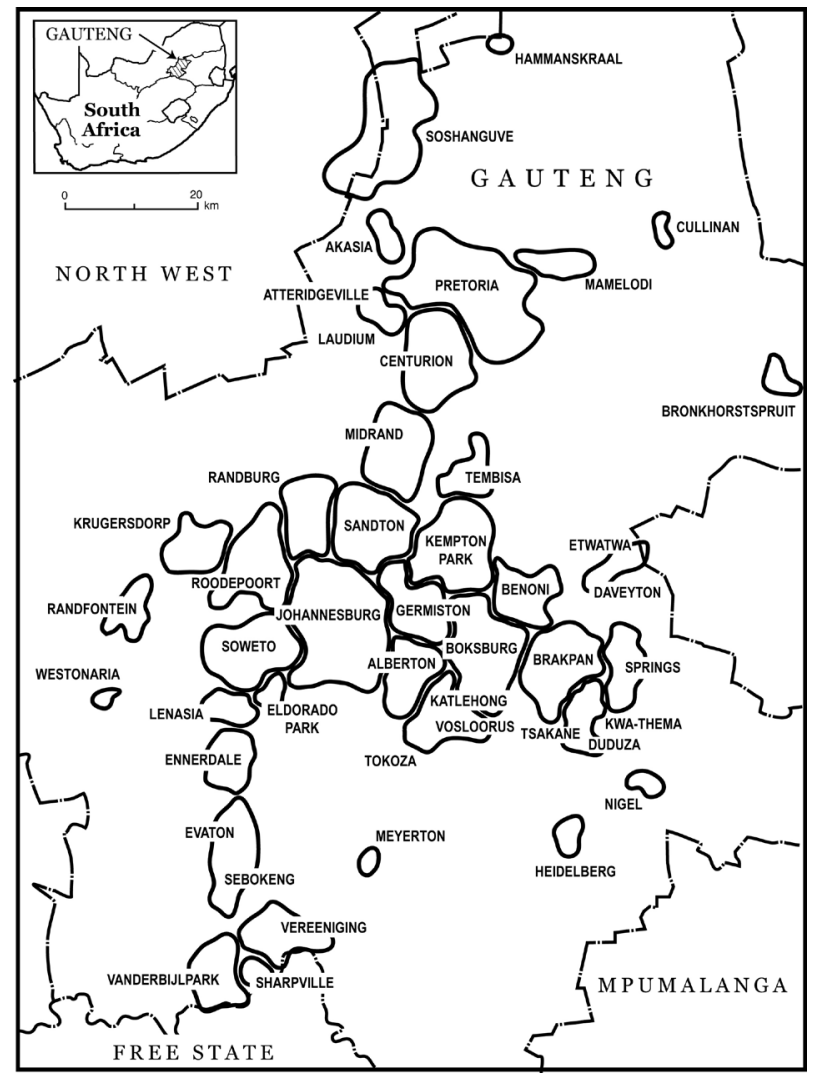

Figure 1. Map of urban centres in Gauteng, demonstrating the urbanised N/S and W/E axis that characterises the province (adapted from SA Routes 2005)

Source: authors, map commissioned by authors from $W$ Job (see acknowledgments) 
segregation alone does not explain why each town in Gauteng is spread out over an unusually large geographical area. Another significant factor was that much of the initial urban development associated with these disparate towns was informal, driven by individual landowners or developers who paid scant regard to effective town planning. Over time, as these far-flung areas were incorporated into the municipal boundaries, low-density development became the norm (Simon 1992; Beavon 2004; Murray 2011). While some of this single, standalone house development can be attributed to the height limitations imposed on construction by the effects of gold mining (earth tremors, rock falls, subsidence and even earthquakes), persistent low land costs and poor management of the urban boundary by municipal governments are largely to blame (Beavon 2004).

The result of sprawling towns is a long and costly commute for everyone. Nevertheless, black African people feel the brunt of it, as they are located far from job opportunities, retail activities and other urban services (a situation that significantly reduces their ability to access services, keep jobs or even accept jobs). This locks black Africans into transport poverty, a situation that has endured over time. A long and costly commute also significantly reduces disposable incomes and quality of life. This spawns a vicious cycle of the poor becoming poorer. Firstly, because they spend so much of their income on transport and secondly because they become locked out of paid employment (Beavon 2001). Thus, spatial segregation and poor urban planning, such as the Development Facilitation Act No 67 of 1995 (only repealed in 2013), has left a damaging legacy on all of Gauteng's cities and its transportation network (Beavon 2004; Turok et al. 2011).

Furthermore, ongoing poor management by city planners has allowed the rise of peripheral shopping malls and office complexes, which now compete directly with the original CBDs (Shaw 2006). This has caused a serious decline in all of the original CBDs and has reinforced urban sprawl. Since the dawn of democracy in 1994, not much has changed. Although there has been recent investment into the Johannesburg and Pretoria CBDs, this has not done enough to balance out the massive investments on the periphery and, therefore, has not reduced urban sprawl. Hundreds of new housing investments and many shopping centres have appeared on the urban periphery, Diepsloot and Cosmo City being but two examples (Beavon 2004). Unfortunately, the public transport network has yet to catch up with this move outwards, so connectivity to these outlying regional centres of office parks, residential complexes and shopping malls requires, for the most part, private vehicles.

Overall, the combination of multiple former mining towns scattered tens of kilometres across the province (Carletonville is $123 \mathrm{~km}$ from Springs and Hammanskraal is $178 \mathrm{~km}$ from Vanderbijlpark), a policy of deliberate spatial segregation and the rise of peripheral developments has resulted in extensive automobile dependence, long trips, congested roads and high transport costs. For example, over $80 \%$ of public transport users and over $40 \%$ of private car users in the province spend more than $10 \%$ of their median income on transport (Venter \& Badenhorst 2014). As Figure 2 demonstrates, the greatest congestion is on roads leading into the two main centres of the province, Pretoria and Johannesburg, meaning that much of the transport costs and road congestion are associated with trips to work and doing business. This ably demonstrates what Pirie (2013:312) notes: "South Africa is struggling to overcome its inherited geo-political past on all spatial scales".

Public transport in Gauteng: A recent political history

In Gauteng, the formal public transportation sector plays only a minor role in terms of overall transport use (Beavon 2004). Results from the 2011 and 2013 Quality of Life surveys conducted by

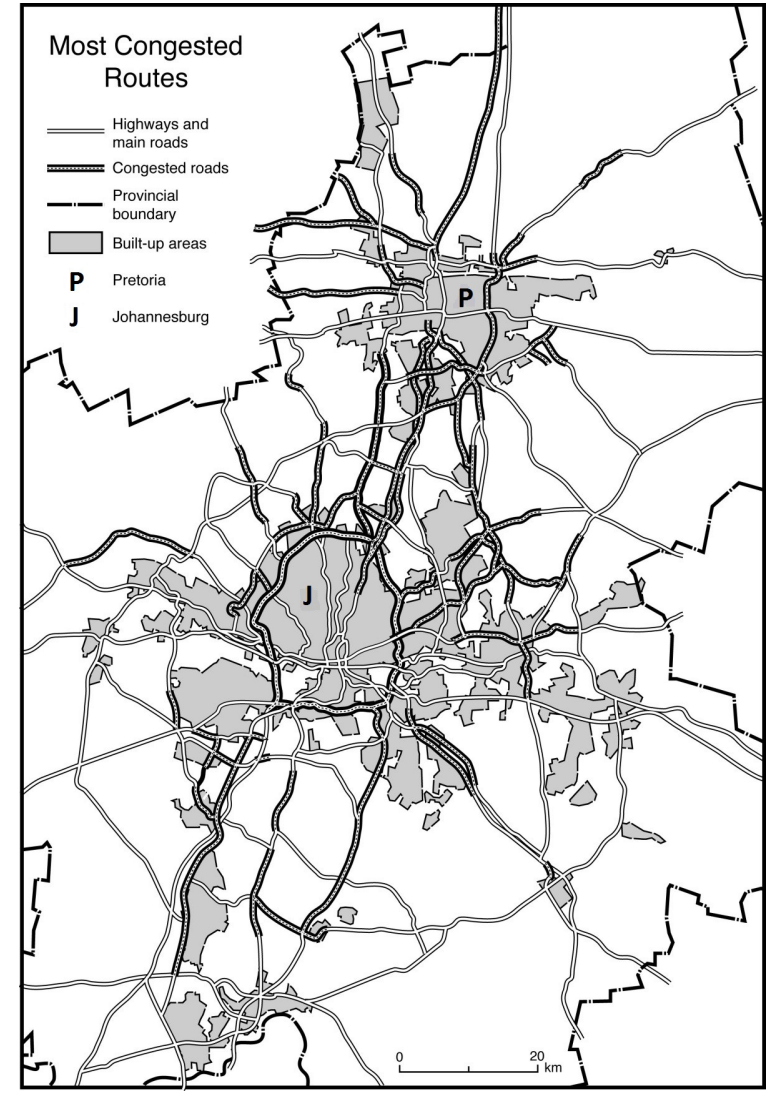

Figure 2. Map showing the most congested roads in Gauteng (adapted from Garner et al. 2001)

Source: authors, map commissioned by authors from $W$ Job (see acknowledgements)

the Gauteng City-Region Observatory (GCRO) show that, of all the trips undertaken in Gauteng, only $3 \%$ were by bus and $5 \%$ were by train (see Venter \& Badenhorst 2014)2. With respect to bus transportation, post-1994, the sector has been plagued by subsidy allocation challenges due to ticket-based contracts (Walters 2010). Under the ticket-based contract system, government subsidizes bus operators based on the number of tickets sold. As this does not allow the Department of Transport to fix subsidy budgets for each financial year, and ticket-based subsidy systems are difficult to monitor and verify, the state has sought to change this. For the government, the solution is a tender-based system (where subsidies are given for kilometres travelled). However, bus operators do not like the tender contract system, claiming it does not cater for increased passenger demand (Walters \& Cloete 2008; Walters 2010). Thus, there has been a dispute between bus operators and government, meaning that contracts (awarded by the Department of Transport between 1997 and 2000) were not revised, even though commuter numbers increased by 20 percent over that period. As a result, buses became overloaded and profit margins thin (Brits 2010; Walters 2010). Consequently, bus companies attempted to keep costs down and, in so doing, reduced the quality and reliability of their service. As a result, buses continue to suffer from a poor reputation with commuters, which is a significant barrier for increasing fares and ridership levels. As ridership levels stagnate, operating costs increase;

${ }^{2}$ Original data available for re-analysis at: http://gcro1.wits.ac.za/qolviewer/Default. aspx?Type=2013S. 
however, the subsidy does not, so more and more bus companies risk commercial failure.

International studies show that trains are a crucial component of public transport but are most efficient when operating within dense corridors and well-integrated with other transport modes (Department of Transport 2005; Kenworthy 2006; Shaw 2006; Schalkwyk 2008; Israel \& Cohen-Blankshtain 2010). However, not only is Gauteng not densely settled, but the passenger rail system is also poorly integrated with other modes of transportation (Shaw 2006; Gauteng Department of Transport 2007). For example, Venter and Badenhorst (2014) report that fewer than 15\% of trips undertaken in Gauteng are 'multimodal', that is, undertaken using a combination of modes. Furthermore, the need to invest in new rolling stock (most of which is currently over 30 years of age) and to improve security in and around train stations, has become acutely apparent. While there are plans afoot to address this, with the Passenger Rail Agency of South Africa (PRASA) investing R123 billion (US\$9.29 billion) to purchase new trains and upgrade train stations, to date only some of the new trains have been purchased, and there is great controversy in the media over their cost and fitness-forpurpose (Myburgh 2015).

It is unsurprising, then, that private cars and privately-owned and operated minibus taxis dominate travel in Gauteng. The private minibus taxi industry is a relatively informal paratransit service that makes use of minibuses to transport paid passengers. The taxis run along fixed routes and can transport between 10 and 20 people at a time. As such they are a type of quasi-public transport system. Half of all the trips undertaken in Gauteng are made using minibus taxi (Venter \& Badenhorst 2014). The minibus taxi industry came into being in the 1970's as a result of a loophole in the Road Transportation Act No 74 of 1977 and is, as such, self-regulated (Schalkwyk 2008). Historically the industry has been marred by violence, poor safety, low profit margins, un-roadworthy vehicles, and overtraded routes (Fourie \& Pretorius 2005; Govender \& Allopi 2006). In 2004, as a means of resolving these challenges, the national government approved a R7.7 billion (US $\$ 581$ million) revised minibus taxi recapitalisation policy (Fourie \& Pretorius 2005). However, Schalkwyk (2008) suggests that this policy was flawed in that not all the role players within the taxi industry (drivers, fare collectors, cleaners and rank marshals), nor the general public, were fully consulted. Furthermore, the policy was only concerned with replacing fleets to increase road safety, and not with curbing route overtrading (Fourie \& Pretorius 2005). Consequently, minibus taxi operators now operate costly new minibus taxis on the same overtraded routes, squeezing profit margins and forcing fare increases (Walters 2010).

To a small degree, some of the problems in both the rail and bus transport domains are dealt with by new projects, such as the Gautrain and Bus Rapid Transit (BRT) projects respectively (Venter 2011). However, in the GCRO 2013 Quality of Life Survey ${ }^{3}$, a massive $94 \%$ of respondents said they never used the BRT, and $99.7 \%$ said they never made use of the Gautrain. Thus, although these projects represent a significant financial step in addressing the public transportation challenges faced by the province, they do not help the majority of residents (Walters 2013). Part of the reason for this is the transport and land use legacy issues.

\section{Methodology}

This study sought to examine past commuter trends in Gauteng using historical transportation data. The one broad research objective was to chart changes in trip generation, trip purpose and modal split in Gauteng over a 28-year period. Various transportation surveys were used: (1) the 1975 PWV Transport Study by the now defunct Transvaal Provincial Administration Roads Department;

${ }^{3}$ Original data available for re-analysis at: http://gcro1.wits.ac.za/qolviewer/Default. aspx? Type=2013S.
(2) the 1985 update of the PWV Transport Study, also undertaken by the Transvaal Provincial Administration Roads Department; (3) the 2000 Gauteng Transport Study (GTS), undertaken by the Gauteng Department of Roads and Transport, and lastly, (4) the 2003 National Household Travel Survey (NHTS), undertaken by the National Department of Transport. For reasons of brevity, these surveys are henceforth referred to as the 1975 PWV Survey, the 1985 PWV Survey, the 2000 GTS and the 2003 NHTS. Because it was the goal of this paper to provide a historical account of transportation trends rather than an overview of the present state of the sector, more recent transportation studies (most notably, the $2013 \mathrm{NHTS}$ ) are ignored as the results thereof are yet to translate into concrete infrastructure developments. In contrast, the studies discussed herein laid the foundation for much past and present transportation infrastructure development in Gauteng.

The Transportation Land Use Planning model (TLUP) has long been the basis for transportation development and travel pattern analysis in South Africa. It also informed the researchers who conducted the various historical surveys analysed here. Thus, this model also informed longitudinal analysis of the data. The TLUP model comprises four stages. These were defined by the 1975 PWV Survey as: (1) Trip Generation - which estimates the number of person trip ends by purpose in each zone based on land use information; (2) Trip distribution - which estimates the number of person trips between zone pairs; (3) Modal split - which allocates the person trips to different transportation modes such as private and public modes, and (4) Traffic assignment - which estimates the number of trips on each link in the network.

Longitudinal data analysis is complicated by the fact that the data sets are collected over an extensive period of time, methodologies may not be similar, and the survey instruments used often have different aims and purposes. Thus, there are limitations to the conclusions which can be drawn from longitudinal data analysis. For example, due to the varying purposes and data collection methods employed across the surveys, it was only possible to conduct analysis on trip generation (including trip purpose) and modal split. Analysis of trip generation and modal split required extensive extrapolation and manipulation to create a uniform data set (Tables 1 and 2 give an indication as to the re-weighting required). Also, due to the racially skewed data obtained in the 1975 and 1985 PWV survey reports, it is advised that a certain degree of caution be used when interpreting the results from these two studies. Furthermore, trip distribution and traffic assignment models could not be explored due to the lack of such data within the 2000 GTS and 2003 NHTS.

For the purpose of this analysis, trip generation was defined as an estimation of the number of trips produced and attracted in a zone or any part of, or entity within, the study area in relation to trip purpose. It also measures activity within the area or entity under consideration. The following terms were used to categorise trip purpose:

1. Home-Based-Work (HBW) trips: trips that either begin at home and end at work or begin at work and end at home;

2. Home-Based-Non-Work (HBNW) trips: these include homebased-shopping trips, home-based-personal-business trips, home-based-social trips and home-based-recreation trips. They either begin or end at home;

3. Home-Based-Education (HBE) trips: such trips begin at home and end at an education institution such as a school, college or university, or vice versa. In the later studies, HBE trips were incorporated into the HBNW trips category, which necessitated similar action in our analysis;

4. Non-Home-Based (NHB) trips: these trips have neither their origin nor their destination as the home of the traveller. NHB trips were not included in the 2003 NHTS. 
Table 1. Trip purpose (1975 PWV Survey, 2000 GTS, 2003 NHTS)

\begin{tabular}{|c|c|c|c|c|c|}
\hline \multirow{2}{*}{\multicolumn{2}{|c|}{ Racial group }} & \multirow{2}{*}{ Sub region } & \multicolumn{3}{|c|}{ Percentage person trips } \\
\hline & & & \multirow{2}{*}{$\frac{\text { HBW }}{31.4}$} & \multirow{2}{*}{$\begin{array}{c}\text { HBNW } \\
56.2\end{array}$} & \multirow{2}{*}{$\begin{array}{r}\text { NHB } \\
12.4\end{array}$} \\
\hline \multirow{6}{*}{1975} & White & $\begin{array}{l}\text { Pretoria, Johannesburg, West Rand, } \\
\text { East Rand, Vaal Triangle }\end{array}$ & & & \\
\hline & Black African & $\begin{array}{l}\text { Mamelodi, Ga-Rankuwa, Atteridgeville, } \\
\text { Mabopane, Soweto, Tembisa, Sebokeng }\end{array}$ & 85.4 & 4.7 & 9.9 \\
\hline & Coloured & Eersterus, Eldorado Park & 87.5 & 6 & 6.5 \\
\hline & Indian & Laudium, Lenasia & 62.5 & 21.5 & 16 \\
\hline & \multicolumn{2}{|c|}{$\begin{array}{l}\text { Weighted data, combined Black African, Coloured and } \\
\text { Indian person trips }\end{array}$} & 78.47 & 10.7 & 10.8 \\
\hline & \multicolumn{2}{|c|}{ Weighted data, all person trips } & 49.6 & 39 & 11.4 \\
\hline \multicolumn{3}{|c|}{ Actual data, all person trips 2000} & 37 & 62 & 1 \\
\hline \multicolumn{3}{|c|}{ Actual data, all person trips 2003} & 27.5 & 72.5 & 0 \\
\hline
\end{tabular}

Table 2. Trip generation by household - average number of trips per day (1975 PWV Survey, 2000 GTS, 2003 NHTS)

\begin{tabular}{|c|c|c|c|c|c|}
\hline \multirow{2}{*}{\multicolumn{2}{|c|}{ Racial group }} & \multirow{3}{*}{$\begin{array}{l}\text { Sub region } \\
\text { ohannesburg, West Rand, } \\
\text { Rand, Vaal Triangle }\end{array}$} & \multicolumn{3}{|c|}{ Percentage person trips } \\
\hline & & & \multirow{2}{*}{$\frac{\text { HBW }}{2.36}$} & \multirow{2}{*}{$\frac{\text { HBNW }}{4.26}$} & \multirow{2}{*}{$\frac{\mathrm{NHB}}{0.96}$} \\
\hline \multirow{6}{*}{1975} & White & & & & \\
\hline & Black & $\begin{array}{l}\text { Mamelodi, Ga-Rankuwa, Atteridgeville, } \\
\text { Mabopane, Soweto, Tembisa, Sebokeng }\end{array}$ & 3.13 & 0.18 & 0.36 \\
\hline & Coloured & Eersterus, Eldorado Park & 2.83 & 0.37 & 0.22 \\
\hline & Indian & Laudium, Lenasia & 2.49 & 0.86 & 0.66 \\
\hline & \multicolumn{2}{|c|}{$\begin{array}{l}\text { Weighted data, combined Black, Coloured and Indian } \\
\text { person trips }\end{array}$} & 2.82 & 0.47 & 0.41 \\
\hline & \multicolumn{2}{|r|}{ Weighted data, all person trips } & 2.6 & 2.83 & 0.84 \\
\hline \multicolumn{3}{|c|}{ Actual data, all person trips 2000} & 0.95 & 1.41 & 0.04 \\
\hline \multicolumn{3}{|c|}{ Actual data, all person trips 2003} & 2.4 & 6.33 & 0 \\
\hline
\end{tabular}

Data on trip purpose and trip generation had to be reformatted such that comparisons across all the surveys could be generated (again, see Tables 1 and 2 for an indication of the re-weighting required). For this reason, the trip purpose and trip generation data from the surveys should be viewed with leniency and should be read rather as a general indication of trip generation and purpose.

As the 1975 PWV Survey defined it, modal split refers to the division of person trips between private and public transport. In this regard, the data from the other surveys was adapted to fit two uniform modal split categories, namely primary modal split and secondary modal split. Primary modal split examined the split between private transport and public transport, whereas secondary modal split examined the split between the individual modes within these two broad categories. The specific modes investigated were as follows: (1) 'Private transport' - travel by car or truck (whether as the driver or as a passenger), as well as by metered taxi; (2) 'Public transport' - buses, trains and minibus taxis (included here because although private they effectively offer a type of public transport service); (3) 'Other transport' walking, motorcycle, bicycle, air travel or animal transport. The analysis of modal split data concentrated solely on HBW trips in the Gauteng region. Due to the skewed representation of race groups in the 1975 and 1985 surveys, it was decided that a better indication of the changes in modal split would be attained by separating the data for these surveys according to race ${ }^{4}$. It should also be noted that, due to ambiguities in the secondary

${ }^{4}$ The data is racially skewed as the apartheid government deliberately underrepresented Coloured, Asian and Black African people in their surveys. modal split data from the 1985 PWV Study, this data set was excluded from the analysis regarding secondary modal split.

Specific methodological limitations of the surveys

The 1975 PWV Survey was undertaken during the apartheid years and, thus, apartheid ideology impacted negatively on the methodology employed. The survey used two different instruments, one for the White population and one for the Coloured, Asian and Black African populations. Data collected for the White population was far more detailed and the sample size was greater. In addition, the two surveys drew their samples from specific geographic areas, making the sample geographically skewed as well (see Tables 1 and 2). Thus, the data collected was biased and is therefore unlikely to be a true reflection of the state of transportation usage, demand and challenges in the province at the time, even with the re-weighting undertaken for this paper. Furthermore, only trips taken from Monday to Thursday were captured, using cordon interviews and road traffic counts. The data was also written up in Afrikaans and had to be translated into English.

The 1985 PWV Survey focused on examining changes in travel patterns and car ownership among the Coloured, Asian and Black African populations as compared to the 1975 PWV Survey, as well as examining the extent to which predictions made in 1975 were borne out in the actual situation in 1985. But the 1985 PWV Survey data is just as racially skewed as the 1975 survey, with very little new data collected and no trip generation data captured. It was therefore necessary to exclude this survey from the analysis regarding trip purpose and trip generation. 
Nonetheless, it was still used for the analysis of modal split, but this was limited to primary modal split, not secondary modal split, once again due to constraints in the data itself.

The 2000 GTS recorded trips taken across the entire week and sampled all of Gauteng's cities and municipalities. It made use of home interviews to collect data. It represents the most thorough and useful study on transportation in the province. Its only major limitation (besides the minor challenges that will inevitably creep into any major transportation study) is that it has not been repeated.

The aim of the 2003 National Household Travel Survey (NHTS) was not to collect data on household trip generation or to model household travel demand, but to collect data on 'typical' weekday trip purpose and to establish household trip generation patterns (Department of Transport 2005). The 2003 NHTS data has a number of constraints. Firstly, it was a national survey and was thus conducted on a much greater scale than all the other three surveys, increasing the margin of error and decreasing opportunities for detail. Secondly, the number of participants in Gauteng was 14,709 fewer than the number who participated in the 2000 GTS. Thirdly, only trips made between Monday and Friday were captured as trips to work. Fourthly, no Non-HomeBased trip data was collected. Lastly, only the following regions within Gauteng were surveyed: East Rand, Johannesburg, Pretoria, Bronkhorstspruit, Cullinan, Carltonville, Krugersdorp, Randfontein, Westonaria, Sterkfontein, Vereeniging, Meyerton and Heidelberg.

Despite these challenges, these surveys are important as they were the only surveys undertaken and there were sufficient commonalities to allow for some comparisons and long term trends to be discerned.

Results and analysis

The data reveals that there was a decrease in HBW trips as a proportion of total trips made between 1975 and 2003 (see Figure 4). However, it is important to note that while proportions have changed, the overall raw number of HBW trips has not declined. Although there is some fluctuation in the average number of HBW trips per household per day, in general this number has remained largely the same (see Figure 5).

Linked to this is an increase in the proportion of HBNW travel compared to HBW travel, with the average number of HBNW trips increasing dramatically between 1975 and 2003 (see Figure 5). Overall, over time, the number of trips that residents of Gauteng make has increased. Thus, demand for transportation increased between 1975 and 2003, outpacing population growth. There could be a number of reasons for this. Firstly, post-1994, freedom of movement for Black African, Coloured and Indian people became a reality, and this led to a significant rise in HBNW travel on the part of these population groups. Secondly, based on the work of Mngaza et al. (2001) and Behrens (2003), it is likely that at least some of the HBNW category consists of Home-Based-Education trips, as the commute to educational institutions has come to constitute a significant feature of life in Gauteng (Bell \& McKay 2011; de Kadt et al. 2014; Machard \& McKay, 2015). Thirdly, it is reasonable to assume that people increasingly travel to access services and leisure activities, which accounts for the surge in reported HBNW travel.

Regarding primary modal split (see Figure 6), it is evident that even in 1975 and 1985, the white population predominantly made use of private vehicles, while people of colour population made equally high use of public transport. In fact, the primary modal splits for the two population groups are almost the inverse of one another. That is, the percentage of public transport use in 1975 and 1985 by the white population was less than $20 \%$, whilst the use of private modes by the people of colour was less

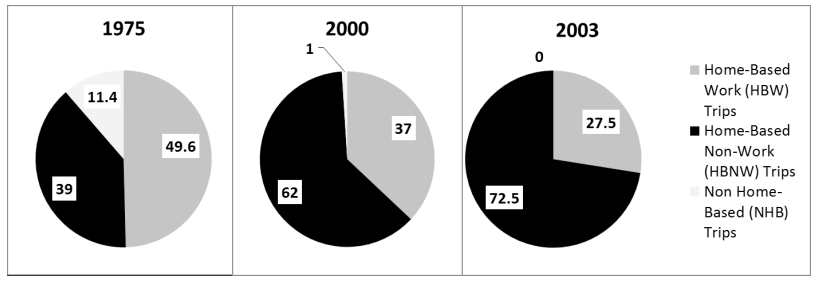

Figure 3. Trip purpose as a proportion of total trips (1975 - 2003) (no data for 1985; 2003 data did not include NHB trips)

Source: authors using the data from the databases described here

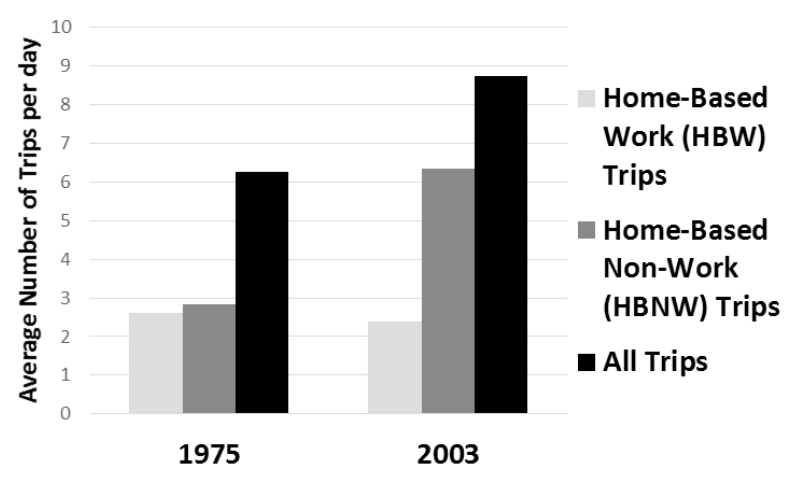

Figure 4. Trip generation in absolute number of trips per household per day (1975 \& 2003) (2003 data did not include NHB trips) Source: authors using the database described here

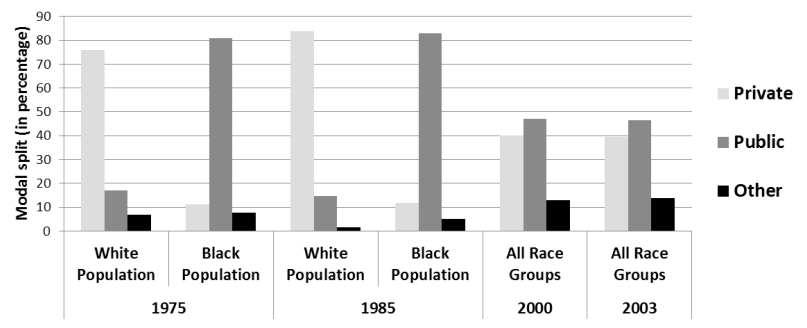

Figure 5. Primary modal split (1975 - 2003) (data for 1975 and 1985 separated by race)

Source: authors, using the database described here

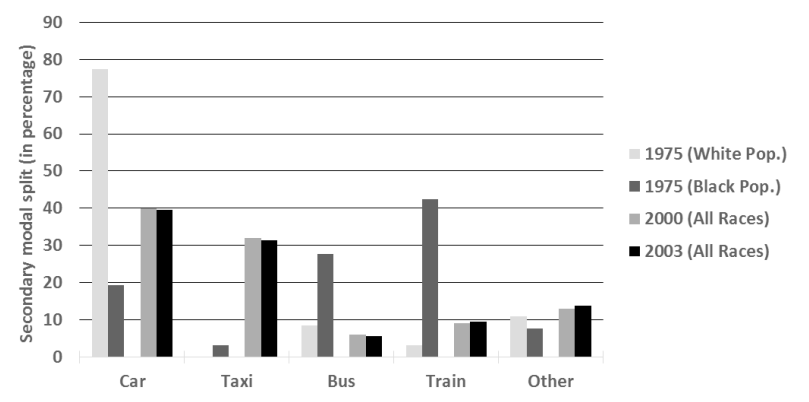

Figure 6. Secondary modal split (1975 - 2003) (no data for 1985; data for 1975 separated by race)

Source: Authors using the database described here

than $20 \%$. However, the consolidated racial data for 2000 and 2003 reveals some change. While public transport remained the leading mode of transport, the percentage by which it exceeded private transport use is now very small. Thus, a significant change is seen for people of all races. Thus, those who are financially 
able are switching to private transport. Results for secondary modal split (see Figure 7) for the Black African, Coloured and Indian population show a striking change in the form of a huge shift from bona fide public transport such as trains and buses to quasi-public transport, namely the minibus taxis, whereas the white population continued to rely on private cars.

\section{Discussion}

Analysis of the historical data illustrates a rapid increase in Gauteng's travel demand. This has strained the province's transportation networks. Indeed, demand for travel, particularly in the form of Home-Based-Non-Work trips, has outpaced population growth. The data also shows that, by 2003, minibus taxis had become the most popular form of 'public' transport, carrying the bulk of the population. This is partly a result of the lack of investment in trains and buses. The study also shows that the middle class (historically, white people, but increasingly multiracial) have become heavily reliant on private transport. The transportation data compiled and reported here was used as input data for 'predict and provide' modelling, and thus, was used to justify road infrastructure improvement projects. However, this means that it has contributed to the establishment of a negative feedback loop by increasing road traffic and straining the transport infrastructure. Consequently, the region has become increasingly dependent on private or quasi-public transportation (cars, trucks and minibus taxis). Even the new (and highly controversial) Gauteng Freeway Improvement Project (GFIP), known colloquially as 'e-tolls', is an outcome of applying the 'predict and provide' model. Importantly then, 'predict and provide' model reinforces the status quo, as the 2013 Quality of Life study proved, with some $81 \%$ of respondents saying the GFIP would not induce them to change their route and $88 \%$ said it would not cause them to change their transport mode ${ }^{5}$. Thus, the spatial and political history of the province has increased reliance on private vehicles over time.

\section{Implications for the present and future}

Although mixed land use densification measures, urban renewal and regeneration projects are strongly recommended for future development, the current spatial infrastructural capital of Gauteng's cities means that transportation networks will have to be built around current land use (Schoeman 2015). However, single use developments are becoming rare internationally so South Africa needs to catch up on this trend (Beavon 2004; Murray 2011). To create a well-organised and successful transportation system is a huge challenge and one that the current BRT and Gautrain projects only very partially address (Pirie 2013; Venter 2011). Thus, it is suggested that mobility issues and public transport provision become a top priority for municipal governments, to the extent that emphasis thereon may necessitate a full assessment of the impact of any new residential, commercial, office or shopping centre developments on infrastructure and public transport. Additional expansion of the city borders must be curtailed. That is, peri-urban space must be defended. The methods employed by Sydney, Australia could provide an example of how to do this (see Mazaza 2002). Naturally, this may bring land owners, real estate developers, real estate agents, banks, corporate financiers and land speculators into conflict with city managers, a situation which will have to be managed (Gruen \& Gruen 2001; Beavon 2004; Murray 2011). Finally, the establishment of a databank of comparable, integrated and reliable transportation data is required if the impact of current and future developments in the transportation sector is to be measured and understood. Sadly, there is already a significant gap with the most recent transportation data for Gauteng more than a decade old. Although a second National Household Travel Survey was undertaken in 2013, this is a national survey, the limitations of which have been explained here; thus, it remains necessary to conduct further transportation studies in the Gauteng Province, specifically, in the near future and regularly thereafter.

\section{Conclusion}

In the Gauteng Province of South Africa, those who are financially able to do so rely on private cars while the rest of the population rely on quasi-public transport namely, minibus taxis, but both are not re major contributors to traffic congestion in the province. The politics of space in the province and the legacy this has had on road infrastructure means that Gauteng is suffering from the negative consequences of past land use policies. These policies now strongly determine transport demand and traffic flows. Spatial apartheid has also strongly contributed to urban sprawl. Thus, poor urban planning haunts the province in the form of long commutes, high transport costs and extended travel times. This study reveals that these trends have been in existence for several decades and have worsened over time. If a permanent shift in modal choice is to be made, genuine public transport provision - in the form of buses and trains - will need great improvement such as enhanced safety, efficiency, accessibility, routes, reduced travel time, better route selection and lower cost. Although the region has witnessed the construction of the Gautrain and Bus Rapid Transit systems, and additional plans are afoot to overhaul the existing rail infrastructure and replace rolling stock, such efforts are fundamentally undermined by current land use patterns. Thus, it is argued here that strong management of the city boundary and the urgent implementation of a mixed land use policy are required if reduced automobile dependence and road traffic congestion is to be achieved. It is also clear that longitudinal transportation data can be used to assist city managers and providers of public transport to make more informed decisions and, therefore, it is recommended that more emphasis is placed on collecting and publishing such data in the future.

\section{Acknowledgements}

We would like to thank the Gauteng City Regional Observatory (GCRO) for their financial support for this study, the UJ library for assisting in tracking down the historical data, Wendy Job of the UJ cartographic unit for the maps, Kerry Chipp for her input to the statistical analysis, Alutius Sithole for assistance with the literature research and Clinton van der Merwe (at the University of the Witwatersrand) for acting as a critical reader. Errors and omissions, however, are our own. 


\section{References}

Beavon, KSO 2001, 'The role of transport in the rise and decline of the Johannesburg CBD, 1886-2001', Proceedings of the $20^{\text {th }}$ Annual South African Transport Conference. Available from: <http://repository.up.ac.za/bitstream/handle/2263/8191/5b4. pdf?sequence=1>. [28 August 2014].

Beavon, KSO 2004, Johannesburg: The Making and Shaping of the City, UNISA Press, Pretoria.

Behrens, R 2003, 'The importance of school and child travel in South African cities and a review of important measures', Proceedings of the $22^{\text {nd }}$ Annual South African Transport Conference. Available from: <http:// repository.up.ac.za/bitstream/handle/2263/7360/Behrens_ Importance\%282003\%29.pdf?sequence=1>. [28 August 2014].

Bell, J \& McKay, T 2011, 'The rise of 'class apartheid' in accessing secondary schools in Sandton, Gauteng', South African Review of Education, vol. 17, pp. 27-48.

Berg, CN, Deichmann, U, Liu, Y, \& Selod, H 2015, 'Transport Policies and Development', World Bank Policy Research Working Paper, (7366).

Beukes, E \& Vanderschuren, M 2011, 'A GIS-Based context sensitive solution for multimodal road planning', Proceedings of the 30th Annual Southern African Transport Conference. Available from: <http://repository.up.ac.za/bitstream/ handle/2263/17327/Beukes_GIS\%20\%282011\%29. pdf?sequence=3>. [28 August 2014].

Brits, A 2010, 'The financial burden of the national road infrastructure and the equity thereof: A South African perspective', Journal of Transport and Supply Chain Management, vol. 4, no. 1, pp. 39-56.

Burgess, R 2000, 'The compact city debate: a global perspective' in Compact Cities: Sustainable Urban Forms for Developing Countries, ed M Jenks, Spon Press, London, pp. 4-17.

Chakwizira, J 2007, 'The question of road traffic congestion and decongestion in the greater Johannesburg area: some perspectives', Proceedings of the $26^{\text {th }}$ Annual Southern African Transport Conference. Available from: <http:// repository.up.ac.za/bitstream/handle/2263/5875/006. pdf?sequence=1>. [28 August 2014].

De Kadt, J, Norris, SA, Fleisch, B, Richter, L \& Alvanides, S 2014, 'Children's daily travel to school in Johannesburg-Soweto, South Africa: Geography and school choice in the Birth to Twenty cohort study', Children's Geographies, vol. 12, no. 2, pp. 170-188.

Department of Transport 2005, Technical Report: The First South African National Household Travel Survey, South African National Department of Transport, Pretoria.

Fourie, LJ \& Pretorius, PJ 2005, 'A call for the radical restructuring of the minibus taxi industry in South Africa', South African Journal of Industrial Engineering, vol. 16, no. 1, pp. 1-11.

Galster, G, Hanson, R, Ratcliffe, MR,Wolman, H, Coleman, S \& Freihage, J 2001, 'Wrestling sprawl to the ground: defining and measuring an elusive concept', in Rates, Trends, Causes, and Consequences of Urban Land-use Change in the United States, eds W Acevedo, JL Taylor, DJ Hester, CS Mladinich \& S Glavac. Available from: <http://pubs.usgs. gov/pp/pp1726/pp1726.pdf>. [28 August 2014].

Garreau, J 1991, Edge city: Life on the new frontier, Anchor Books, New York.

Garner, D, Louw, JP \& Burnett, SL 2001, 'Towards resolving congestion in Gauteng', Proceedings of the $20^{\text {th }}$ Annual South African Transport Conference. Available from: <http:// repository.up.ac.za/bitstream/handle/2263/8174/4b3. pdf?sequence=1>. [28 August 2014].
Gauteng City-Region Observatory, 2013. Available from: <http:// gcro1. wits.ac.za/qolviewer/Default.aspx?Type=2013S>. [28 August 2014].

Gauteng Department of Transport 2007, Integrated public transportation action plan for Gauteng province, Available from: <http://www.uect.org.za/docs/Gauteng\%20Strategic\% 20Action\%20Agenda\%2020_8_07.pdf>. [24 June 2011].

Govender, R \& Allopi, D 2006, 'Towards a safer minibus-taxi industry in South Africa', Proceedings of the $25^{\text {th }}$ Annual South African Transport Conference. Available from: <http:// repository.up.ac.za/bitstream/handle/2263/6052/022. pdf?sequence=1>. [28 August 2014].

Gruen, NJ \& Gruen, C 2001, You may not realize it, but we're actually living in a revolutionary time, Available from: <http:// www.ggassoc.com/publications/2001-08b.pdf>. [28 August 2014].

Hamidi, S \& Ewing, R 2014, 'A longitudinal study of changes in urban sprawl between 2000 and 2010 in the United States', Landscape and Urban Planning, vol. 128, pp. 72-82.

Harden, C 2011, Get transit-orientated, Available from: <http:// www.transit-orientated.com>. [29 June 2011].

Israel, E \& Cohen-Blankshtain, G 2010, 'Testing the decentralization effects of rail systems: empirical findings from Israel', Transportation Research, vol. 44, pp. 523-536.

Kenworthy, JR 2006, 'The eco-city: Ten key transport and planning dimensions for sustainable city development', Environment and Urbanisation, vol. 18, no. 1, pp. 67-85.

Machard, D \& McKay, TJM 2015, School choice, school costs: The case of inner city Johannesburg Private Schools, Acta Academica, vol. 47(2), pp. 139-162.

Mattingly, K \& Morrissey, J 2014, 'Housing and transport expenditure: socio-spatial indicators of affordability in Auckland', Cities, vol. 38, pp. 69-83.

Mazaza, M 2002, 'The transportation/land use connection: a dilemma for the $21^{\text {st }}$ century city', Proceedings of the $21^{\text {st }}$ Annual South African Transportation Conference. Available from:< http://repository.up.ac.za/bitstream/ handle/2263/7831/036.pdf? sequence=1>. [28 August 2014].

Mngaza, K, Dhlamini, P \& van Zyl, O 2001, 'Addressing learner transport issues in Gauteng', Proceedings of the 20th Annual South African Transport Conference. Available from: <http:// repository.up.ac.za/bitstream/handle/2263/8077/2c12. pdf?sequence=1>. [28 August 2014].

Murray, MJ 2011, City of extremes: The spatial politics of Johannesburg, Wits University Press, Johannesburg.

Myburgh, P-L 2015, PRASA trains don't fit. Available from: <http:// www.news24.com/SouthAfrica/News/Prasa-trains-dont-fit20150712>. [28 August 2014].

Parnell, S \& Beavon, K 1996, 'Urban land restitution in postapartheid South Africa: Questions from the Johannesburg inner-city', Geojournal, vol. 39, pp. 13-19.

Pirie, G 2013, 'Transport geography in South Africa', Journal of Transport Geography, vol. 31, pp. 312-314.

Rodrigue, J-P, Comtois, C \& Slack, B 2006, The geography of transport systems, Routledge, London.

Rooney, D 2014, 'The political economy of congestion: Road pricing and the neoliberal project, 1952-2003', Twentieth Century British History, pp. 1-23.

SA Routes 2005, Gauteng Map. Available from: <http://www. routes.co.za/gp/map-general.html>. [28 August 2014].

Schalkwyk, D 2008, 'Institutional statism: An overview of the formulation of the taxi recapitalisation policy', Koers, vol. 73, no. 4 , pp. $771-791$ 
Scheiner, J 2010, 'Interrelations between travel mode choice and trip distance: Trends in Germany, 1976-2002', Journal of Transport Geography, vol. 18, pp. 75-84.

Schoeman, IM 2015, 'Determination and ranking of integration measures for land use and transportation applications', Urban Transport XXI, vol. 146, pp. 15-25.

Serageldin, I 1993, 'Environmentally sustainable urban transport - defining a global policy', Public Transport International, vol. 42, no. 2, pp. 14-22.

Shaw, A 2006, 'Achieving a pro-public transport agenda in South Africa - the challenge for middle income countries', WIT Transactions on the Built Environment, vol. 89, pp. 805815.

Simon, D 1992, 'Reform in South Africa and modernisation of the Apartheid City' in Urban and Regional Change in Southern Africa, ed DW Drakakis-Smith, Routledge, London.

Stapelberg, H 2006, 'The role of transport planning in the quest for sustainable land use', Proceedings of the $25^{\text {th }}$ Annual Southern African Transportation Conference. Available from: <http://repository.up.ac.za/bitstream/ handle/2263/6077/041.pdf?sequence=1>. [28 August 2014].

Turok, I, Hunter, R, Robinson, B, Swilling, M \& van Ryneveld, P 2011, State of the cities report. Available from: <http://www. sacities.net/knowledge-centre/research/publications/25what-we-do/socr/607-socr-2011-report>. [28 August 2014].
Venter, C 2011, 'Transport expenditure and affordability: the cost of being mobile', Development Southern Africa, vol. 28, no. 1, pp. 121-140.

Venter, C \& Badenhorst, W 2014, '2011 GCRO Quality of Life Survey: Analysis of transport data' in Mobility in the Gauteng City-Region eds C Wray \& G Gotz. Available from: $<$ http://www.gcro.ac.za/media/reports/mobility_report_ july_28_2014_medium_res_2.pdf>. [27 August 2014].

Walters, J 2010, 'Is the bus transport contracting system in South Africa leading to trusting relationships between contracted parties? An analysis of funding issues and the impact on relations between government and operators', Research in Transportation Economics, vol. 34, pp. 236-243.

Walters, J 2013, 'Overview of public transport policy developments in South Africa', Research in Transportation Economics, vol. 39 , no. 1 , pp. 34-45.

Walters, J \& Cloete, D 2008, 'The South African experience with negotiated versus competitively tendered bus contracts', Transportation Research Part A, vol. 42, pp. 1163-1175.

Zhao, P 2010, 'Sustainable urban expansion and transportation in a growing megacity: Consequences of urban sprawl for mobility on the urban fringe of Beijing', Habitat International, vol. 34, pp. 236-242. 